\title{
Airport Disaster Preparedness Program: A Lesson Learned from Recent Indonesia's Earthquake in 2018
}

\author{
Herqutanto, MD, PhD, ${ }^{1 *}$ Trevino A. Pakasi, MD, PhD, ${ }^{1 *}$ Albert Wijaya, MD, Sp.KP² and Garry Anthony, MD, Sp.KP2 \\ ${ }^{1}$ Department of Community Medicine, Faculty of Medicine, Universitas Indonesia

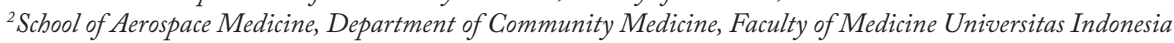

\begin{abstract}
Introduction. In the event of a disaster, an airport serves two essential roles, as the central hub for incoming supplies such as food and medication and provide a lifeline to the affected communities, and as a coordination and information center to register, brief, and task for the incoming humanitarian organizations and rescue teams. What happens if the disaster itself impacts the airport? This paper describes the conditions at Palu airport during an earthquake and the state one year after.
\end{abstract}

Method. This is a qualitative study, utilizing information gathered from interviews, articles in newspapers, and reports from official websites. Findings from the official websites were confirmed with findings from newspapers or other printed media and were also confirmed with the results of the observations and interviews. The interviews were conducted with several key informants at the airport. Data were then analyzed verbatim and written in a narrative description.

Result and Discussion. Many factors contributed to the chaos at Palu Airport. The earthquake's impact was significant enough for a small airport such as Palu Airport. There was no clear incident command system and coordination between institutions within the airport and the city. There was a lack of disaster readiness planning and regular training before the earthquake. The first initial training in 2009 was not followed up.

Conclusion. The 2018-earthquake in Palu was a big disaster that impacted the airport. Lack of capacity was related to the discontinuity of the 2009 training into a continuous disaster management program. The unclear management system inside the airport and the local authority worsened the impact of the disaster on both the airport and the community.

Key Words: airport disaster preparedness, natural disaster

\section{INTRODUCTION}

A tectonic earthquake with a magnitude of 7.7 occurred in Donggala, Central Sulawesi, Indonesia, at 06.02.44 PM $(\mathrm{GM}+8)$ on September 28, 2018. The quake struck at a shallow depth of $10 \mathrm{~km}$ and was located $26 \mathrm{~km}$ north of Donggala. Donggala is a regency in Central Sulawesi province, $75 \mathrm{~km}$ away from its capital, Palu, where the airport is domiciled. The shaking was felt as far away as Samarinda,

*Both share the first authorship.

Corresponding author: Trevino A. Pakasi, MD, PhD

Department of Community Medicine

Faculty of Medicine

Universitas Indonesia

Jl. Pegangsaan Timur no.16, Jakarta Pusat, Indonesia

Email. pakasitrevino@gmail.com the capital of East Kalimantan, the big opposite island to the west of Sulawesi, and Makassar, at the southern part of Sulawesi. Allegedly, 4438 people were injured, 2081 died, and 1330 were still missing, as reported on October 23, 2018. ${ }^{1,2}$ Many buildings were destroyed. The telecommunication line got cut off, making it difficult to call for help. There have been delays in aid because most roads were damaged. 
The Mutiara Sis Al-Jufri Airport, the only airport in Palu, the capital of Central Sulawesi province, became less able to evacuate the victims after being damaged by the disaster.

In the immediate aftermath of a disaster, an airport serves two critical roles. First, an airport is widely used as the central hub for incoming supplies such as food and medication and provides a lifeline to affected communities. Second, an airport (initial) coordination and information center to register, brief, and task the incoming humanitarian organizations and rescue teams. ${ }^{3}$

However, airports are not immune to disasters. It may be directly or indirectly affected by the disaster itself that will somehow limit their capacity to support the humanitarian response, as in the experience of Lombok's airport. ${ }^{4}$ This situation has been anticipated since Palu Airport received training in 2009 about disaster preparedness. The training was called Get Airports Ready for Disaster (GARD), endorsed by the United Nations Development Program (UNDP), trained by the Deutsche Post DHL (DPHDL) group, and funded by the government of Germany. The training was to achieve airport disaster preparedness planning and introduce contingency planning and assessment. ${ }^{5}$

Eleven years after the training, an actual situation happened and struck the airport. It is essential to see what worked and find the reason for further anticipation when a similar disaster happens because Indonesia is prone to natural disasters. The study aimed at observing implementing GARD during the Palu disaster and the impact of the impact disaster approximately one year after the disaster. By understanding the problem and how they handled the chaotic situation in observation after one year, other airports may learn from the experience, especially Indonesia, and prevent further damage when a disaster occurs.

\section{METHODS}

\section{Study design}

The study used a qualitative design because each disaster and its impact were unique and specific and could not be quantified. The assessment started with analyzing existing reports available to the public. We collected data from various credible websites and interpreted documents. The official websites were BNPB (the national body to respond to disasters), UNDP, DPDHL (Deutsche Post DHL Group), and AHA (ASEAN Humanitarian Assistance) centers. Official websites of the newspapers were gathered from Strait Times, The Jakarta Post, and the local newspaper. We used the keywords earthquake, Palu, and airport to find the relevant articles. Following the reading in the newspapers, we did several interviews with selected informants who were present during the disaster.

\section{Recruitment}

Key persons were recruited from the airport staff, the management staff, and the eyewitnesses to the disaster. We interviewed the airport head, medical officer, safety officer, air traffic control officer, and airport apron movement control officer regarding the management staff. The process started with providing general information about the study to airport management, such as the purpose, time to visit, an observation that will be included, and an interview with the officers. After it was officially approved, we visited the airport of Palu and conducted the discussion there. Field observation to some areas in the airport that used to be impacted was also conducted.

\section{Data collection and instrument}

Primary data collection started in September 2018 and ended August 26,2019, approximately one year after recovery. Secondary data was collected on official websites on the disaster. Findings from the official website were confirmed with findings from newspapers or other printed media and were also confirmed with the results of the observation and interview.

Each participant provided informed consent and was asked for background demographic characteristics. Next, we interviewed each participant with an interview guideline to ask about the day when Palu's disaster and what happened to the airport operation afterward. Probing questions were used to supplement the main question. Following the description of the catastrophe, we explored the implementation of the past GARD training within the airport. The questions were related to the purpose of the training, the material given, and the performance afterward. The question was deepened on how the training reached the goal through their daily activities before the disaster.

The guide for the interview was developed based on information from primary data collection, starting from identity and current title and the role in disaster management. The questions continued to ask descriptions of the earthquake, the impact of the disaster in general, and more specifically, to the airport. Direct information is being explored more, as have already some based information at the Palu Airport.

\section{Data analysis}

The recorded interviews were transcribed and listened to, to check for accuracy of the transcription. All authors read the transcription repeatedly and coded them to identify patterns, categories, and themes. Initially, data were categorized and then coded independently according to the topic. Analytic coding was used to determine the meaning of the data and its significance. The team regularly met up to discuss data analysis to achieve consensus. We used adequate engagement, investigator triangulation, and member checking to clarify meaning and evaluate the interpretation of data.

\section{Ethical clearance}

Ethical clearance was granted from the ethical committee; Faculty of Medicine Universitas Indonesia no. KET-10/UN2.F1/ETIK/PPM.00.02/2019. 


\section{RESULTS}

Characteristics of key informants who were interviewed at Palu airport one year after the disaster were as follows

Table 1. Demographic characteristics of key informants

\begin{tabular}{|c|c|c|c|}
\hline Initial & Sex & Position & $\begin{array}{c}\text { Length of } \\
\text { working in Palu }\end{array}$ \\
\hline $\mathrm{KB}$ & M & Head of the airport & $>5$ year \\
\hline L & $\mathrm{F}$ & Medical staff of the port health & $<1$ year \\
\hline Z & M & Aviation Security & $>5$ year \\
\hline$S$ & M & Aviation Security & $>5$ year \\
\hline A & M & Safety officer & $>5$ year \\
\hline B & M & Safety officer & $>5$ year \\
\hline C & M & Apron Movement Controller & $>5$ year \\
\hline $\mathrm{D}$ & M & Air Navigation Indonesia & $>5$ year \\
\hline
\end{tabular}

All participants aged more than 30 years, married, and had their families in Palu, except for one safety officer whose family lived in Java, a different island than Sulawesi, where Palu is located. All key informants except one had to work during emergencies while at the same time they needed to take care of their families.

The key informants were all eyewitnesses to the disaster and had worked for more than five years, but none were admitted to attend the GARD training in 2009. Their positions were appropriate to provide information about the disaster at the airport.

\section{Emergency in Palu Airport}

Based on existing reports, Palu Airport was damaged on the runway, and the air traffic control (ATC) tower collapsed. ${ }^{6}$ The airport head stated that it was dark without electricity and no means of communication was available. However, he could finally call Jakarta (Capital of Indonesia) and report the damage at the airport and stated that the airport was shut down due to the damage. A crack occurred at the $500 \mathrm{~m}$ point of the $2,500 \mathrm{~m}$ runway, making it impossible for large aircraft to land (Figure 1). The airport's air traffic control (ATC) tower was damaged and collapsed, impairing the navigation system. As a result, Hercules and CN-235 (a medium-range twin-engine transport aircraft) were the only cargo aircraft, which could transport aid and evacuate people. ${ }^{6}$ The airport closed for commercial flights from September 28 until September 30, 2018. ${ }^{7}$

On the following day, an ATC team came from Makassar, South Sulawesi, to restore the function of the ATC. The head of the ATC tower confirmed the information that the ATC team from Makassar came to assist the ATC staff at Palu. It was a consensus among the team to release local staff during the disaster because the ATC team understood that the affected local staff needed to take care of the families, too, since they were also victims of the disaster. According to the head of AirNav in Palu, it would be impossible for the local team to work in full concentration. One year later, as it was observed, the airport still used the temporary ATC tower. The permanent tower had not yet been built, said the head of AirNav in Palu. The procurement process was not easy in the central government, he explained.

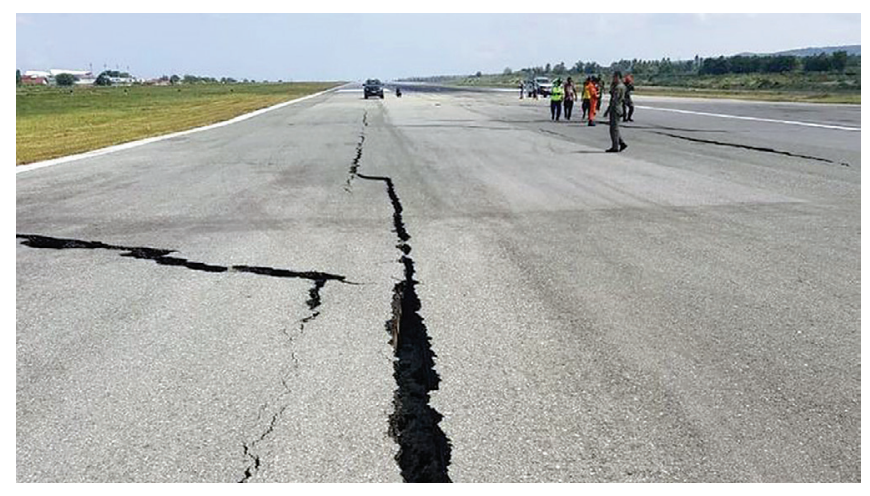

Figure 1. Mutiara airport runway cracked, and only small propeller aircraft and military airplanes could land.

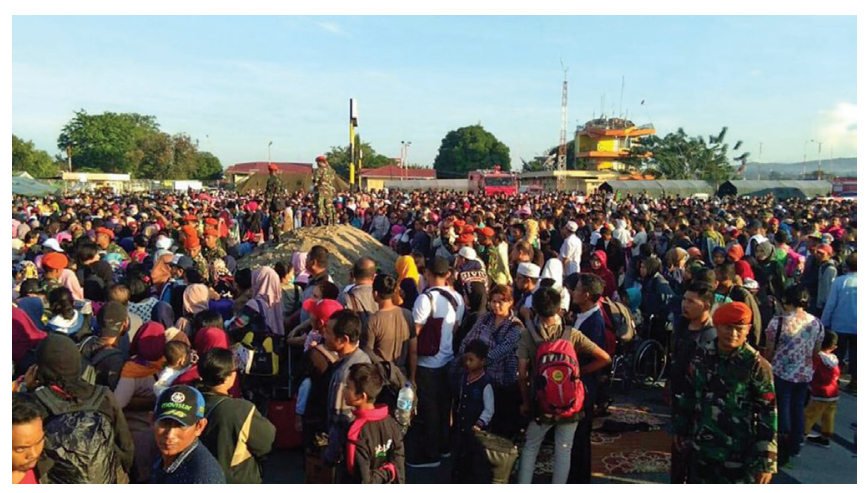

Figure 2. People waiting on Mutiara's airport runway.

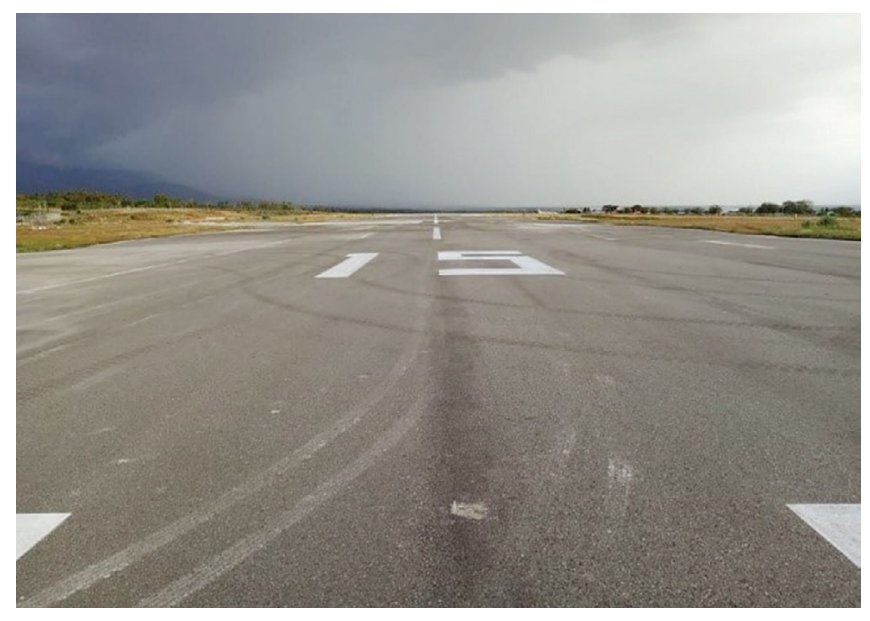

Figure 3. Section of runway 15 repaired over two weeks, allowing Airbus and Boeing narrow-body aircraft to resume operations. 
Besides severe damage to the airport of Palu, many people rushed and camped at the airport, hoping to flee the devastated area. This made the airport more chaotic, as shown in Figure 2. The chaos at the airport further created a bottleneck for delivering supplies and evacuating the victims. ${ }^{8-11}$

According to the head of the airport, the runway was repaired, and on the second day, it could serve smaller aircrafts (i.e., ATR) because the effective runway was 2000 x $45 \mathrm{~m}$. (Figure 3) Slowly, when they had renewed and recovered the runway, larger aircraft with limited capacity could land to bring logistics.

The replacement team, as the ATC team was not available for all airport staff. In many disasters, it was expected that the military would come to take over the airport management, and so it was in Palu. The military troops arrived to take over the airport management.

At that time, the airport head felt the possibility of receiving a commercial airport, but the military forbade it because it was an emergency. It took approximately two weeks to recover the crack at the runway until the personnel from The Indonesian army could reopen the airport. During that period, humanitarian aid and teams came only through military flights or under their control.

As one of our key informants told us, the airport authority was confused about receiving command between the military and the airport authority. According to the safety officers, there was no coordination between the authorities (military, airport management, or the National Disaster Management Agency) to decide who would be the incident commander in this situation. Moreover, the city and provincial governments seemed to be less functioning because of the damage. In this situation, it is expected that military staff will take over the government to maintain security in the impact area.

\section{GARD Training}

GARD was an airport preparedness program launched in 2009 by the United Nations Development Program (UNDP) and Deutsche Post DHL Group (DPDHL) and funded by the government of Germany. GARD was a workshop-based training program that prepared airports and trained airport personnel in high-risk countries for worst-case scenarios. ${ }^{12}$

Indonesia became the first country to host GARD training in 2009, located in Palu - and Makassar airport. ${ }^{13}$ The training objectives were to increase airport preparedness and introduce contingency planning and assessment, besides report writing during a disaster. The outcomes were, the two airports would have trained personnel and a detailed report with recommendations for future airport relief operations. Participants in the GARD training were the Airfield Operations Managers, Air Traffic Control Managers, Cargo Managers, and Security Managers. Participants were divided into three groups: i) Inflow; ii) Activities; iii) Outflow. Each group was responsible for assessing a specific function of the airport and its response ability during a disaster, finding solutions, and reporting on the particular area. The three areas examined were cargo, passengers, and airport operations (i.e., getting information on the capacity of the airport to have a certain number of inflight and outfight activities and to host an emergency hospital/medical facility eventually). ${ }^{14}$

GARD training was documented in the Airport Surge Capacity Assessment Report (ASCA) and led to an action plan for increasing the airport's maximum capacity. There was also a refreshment course called GARD plus six-to-twelve months after the initial workshop to review the material, deepen knowledge, and help participants put what they have learned into practice. ${ }^{5,13}$ The Directorate-General for Civil Aviation of the Indonesian Ministry of Transportation recorded the second phase of GARD training in 2012. We assumed the training for Palu had similar topics, as well as what was documented by UNDP. The follow-up of the training required each participant to regularly report the achievements of the disaster management at the airport, though there was a disaster. The UNDP wrote that the target of the training was the writing of the action plan and regularly reporting how many exercises were carried out in the implementation of the action plan. ${ }^{15}$

The head of the airport and his staff were unaware of the disaster preparedness program and the GARD training. To the best of our knowledge, there was no data of GARD's continuity training in Indonesia since 2009. There was no other training to prepare airport staff during a disaster, i.e., basic and advanced life support training, which was also lacking. Before working at the airport, the official health port staff did not have any public health emergency training or disaster management activity. We asked about the record of regular training at the airport. Though they admitted the training was done regularly, they could not show any records of the activities. Moreover, after the impact, the GARD meeting was done in Bali, but according to the safety officers, they struggled to make the document for airport emergency planning.

\section{DISCUSSION}

The chaos at Palu Airport happened because of many factors. First, the impact of the earthquake was significant enough for a small airport such as Palu Airport. Second, there was no clear incident command system and coordination between the airport and the city institutions. Third, disaster readiness planning and training was lacking.

The surge of people at the airport who wanted to evacuate and the bottleneck of humanitarian aid through airplanes happened because of the crack in the runway. They destroyed the ATC tower, exacerbated by blackouts of electricity and broken roads. People were faced with uncertainty, became confused, and desperately wanted to get out of the devastated area as soon as possible. However, no airport officer could inform the precise planning to recover. 
It became clear that the airport was vital in disaster as the central logistical hub for incoming relief supplies, providing a lifeline to the affected communities and serving as the (initial) coordination and information center.

The most important contributor to the situation was the lack of the incidence command system. Though the airport head did not admit it, we still observed that such procedure was lacking at the airport of Palu and the local government. There was no clear commander during the disaster, whether the head of the airport or, at a certain level, the military should take over it. There was a standard procedure for the military to take over when damage was significant. However, it was not clear to the airport's operational staff. Thus, it created confusion as to whether to obey the head of the airport or the military. It was also a debate between the military and airport authorities about whether or not to open commercial flights. There would not have been a problem if an airport emergency plan had stated the airport's criteria for when to operate following a disaster.

The impact of the command system was coordination between all relief programs from different institutions and how to manage internally displaced populations (IDPs). Management of the IDPs should come more from the local government rather than coming from the airport. For logistics and humanitarian aid, the airport functions as a hub and might be the first place for registration and coordination to the local incident command system in the area.

After 2009, with first training in Palu and Makassar, GARD was initially rolled out as a program in other airports in Indonesia by trained DHL experts and deployed to train the local counterparts. However, there were no signs of deployment and continuity to other airports. Moreover, Palu airport did not follow training recommendations and regularly practiced the incidence command system. There was no information on the airport preparedness program in Palu even though they had GARD training in 2009. As far as we understood, the current head of the airport was new and under different management, different from when the GARD training was held. This might be the reason training in Palu was not continued. The Palu airport should have been ready for the disaster if they continuously did the exercise or drilling as part of the GARD training implementation.

It was fundamental for the airport as well as many institutions in anticipation of disasters. The GARD training has been disseminated to many countries all over the world. We did not have sufficient information on how the training was followed-up. Still, this study reminded us to continue drilling to implement the GARD training and evaluate it routinely.

Having collected the data and observed the situation, the need for airport preparedness is critical because Indonesia is a country that is prone to natural disasters. For that, we can use GARD training as a starting point. The training included assessing the airport's maximum processing capacity (goods and passengers), identifying action measures to quickly increase airport capacity in the event of a natural disaster, identifying possible bottlenecks at their airport, and developing concrete steps for avoiding such logjams. The training is essential because the results are documented in the Airport Surge Capacity Assessment Report (ASCA), an action plan for increasing the airport's maximum capacity. Such a report is vital to making the airport more prepared for handling natural disasters. Doing so is required on government and airport authorities to endorse the program and cooperate with UNDP and DPDHL to perform the training.

\section{CONCLUSION}

The 2018-earthquake in Palu was a big disaster that impacted the airport, whose capacity was not as much as expected, though the personnel had been trained in 2009. Lack of capacity was related to discontinuing the first training into a continuous disaster management program as described during the interview. Moreover, an unclear management system inside the airport and that of the local authority worsened the impact of the disaster on both the airport and the community.

\section{Statement of Authorship}

All authors contributed in the conceptualization of work, acquisition and analysis of data, drafting and revising, and approved the final version submitted.

\section{Author Disclosure}

All authors declared no conflicts of interest.

\section{Funding Source}

This study was funded by the Directorate of Research and Public Engagement Universitas Indonesia.

\section{REFERENCES}

1. BNPB website: Gempa Bumi Sulteng. [Internet\}. 2018 [cited 23 October 2018]. Available from: https://sites.google.com/view/ gempadonggala/beranda

2. AHA website AHA-Situation Update. [Internet]. 2018 [cited 23 October 2018]. Available from: https://ahacentre.org/wp-content/ uploads/2018/10/AHA-Situation_Update-no14-Sulawesi-EQ-rev2. pdf.

3. Smith JF. Airport Disaster Preparedness in A Community Context (Final Report). American Public University System, 2009.

4. Tribun news website: Selama Gempa, Bandara Internasional Lombok Akan Beroperasi 24 Jam. 2018. [Internet]. [cited 24 October 2018]. Available from: http://wartakota.tribunnews.com/2018/08/07/selamagempa-bandara-internasional-lombok-akan-beroperasi-24-jam].

5. Airport Technology: Guarding against Disaster: GARD prepares airports for crisis. [Internet\}. 2018 [cited 24 October 2018]. Available from: https://www.airport-technology.com/features/featureguardingagainst-disaster-gard-prepares-airports-for-crisis-4627954/.

6. Flight global website: Indonesia's Palu airport to undergo repairs after disasters. [Internet\}. 2018 [cited 24 October 2018]. Available from: https://www.flightglobal.com/news/articles/indonesias-palu-airportto-undergo-repairs-after-di-452422/. 
7. The Jakarta Post website: palu-airport-reopens-for-commercialflightsfollowing-earthquake. [Internet\}. 2018 [cited 24 October 2018]. Available from: http://www.thejakartapost.com/news/2018/09/30/ palu-airport-reopens-for-commercial-flightsfollowing-earthquake. html

8. Flight Global website: Indonesia's Palu airport resumes limited operations. [Internet\}. 2018 [cited 24 October 2018]. Available from: https://www.flightglobal.com/news/articles/indonesias-palu-airportresumes-limited-operations-452309/

9. Strait Times website: fleeing-palu-residents-hampered-by-fuelshortage-crime-and-air-chaos. [Internet\}. 2018 [cited 24 October 2018]. Available from: https://www.straitstimes.com/asia/se-asia/ fleeing-palu-residents-hampered-by-fuel-shortage-crime-and-airchaos.

10. The Jakarta Post web site: Chaos in Palu after Quake as Survivors Deal with Hunger, Thirst. [Internet\}. 2018 [cited 24 October 2018]. Available from: http://www.thejakartapost.com/news/2018/10/01/ chaos-in-palu-after-quake-as-survivors-deal-with-hunger-thirst.html

11. Solo Pos website: Kacau Pasca-Tsunami, Warga Duduki Bandara Palu Berebut Tumpangan Hercules. [Internet]. 2018 [cited 24 October 2018]. Available from: http://news.solopos.com/ $\mathrm{read} / 20181001 / 496 / 943167 / \mathrm{kacau}$-pasca-tsunami-warga-dudukibandara-palu-berebut-tumpangan-hercules.
12. UNDP website: Get Airports Ready for Disaster. [Internet\}. 2018 [cited 24 October 2018]. Available from: http://www.europe.undp. org/content/geneva/en/home/partnerships/get-airports-ready-fordisaster--gard-.html.

13. DHPHL website: Disaster Preparedness. [Internet]. 2018 [cited 24 October 2018]. Available from: https://www.dpdhl.com/en/ responsibility/society-and-engagement/disaster-management/ disaster-preparedness.html.

14. Directorate General of Civil Aviation of the Indonesian Ministry of Transportation, [Internet\}. 2012 [cited 25 November]. Available from: http://hubud.dephub.go.id/website_en/AgendaDetail.php?id=158

15. UNDP website: Get Airport Ready for Disaster [Internet\}. 2016 [cited November 2021]. Available from: https://info.undp.org/docs/pdc/ Documents/H10/GARD\%20Project\%20Document,\%202016-2017. pdf

Have you read the current trends in Medical and Health Research in the Philippines?

\title{
Acta Medica Philippina The National Health Science Journal
}

\author{
Access Online: www.actamedicaphilippina.upm.edu.ph
}

